Article

\title{
Between Toleration and Emancipation: The Self-Empowerment of Jewish Intellectuals in the Habsburg Monarchy
}

\section{Louise Hecht}

Kurt and Ursula Schubert Center for Jewish Studies, Palacký University, tř. Svobody 26, Olomouc 77900, Czech Republic; louise.hecht@upol.cz

Academic Editors: Peter Iver Kaufman and Malachi Hacohen

Received: 6 February 2017; Accepted: 23 May 2017; Published: 16 June 2017

\begin{abstract}
Analyzing a sample of prominent Jewish intellectuals from the Bohemian lands, this article explores Jewish networks as well as cultural and political activism in the Vormärz period and during the 1848 revolution. It seeks to answer the question of whether Joseph II's 'Edicts of Toleration' had, unintentionally, generated a new group within Jewish society that was determined to fight for their rights. Already during the Vormärz period, these Jewish intellectuals enjoyed a high level of social integration, but also fought the repressive structure of the Metternich regime. After the removal of legal discriminations in 1867 , the majority felt a deep sense of loyalty to the state and significantly enriched the cultural and political life of the Monarchy.
\end{abstract}

Keywords: Empire; Socialism; Jews; Habsburg Monarchy; Vormärz; 1848 Revolution; Edicts of Toleration; Joseph II; emancipation; discrimination

In the winter of 1781 to 1782, the German-Jewish enlightener and Hebraist Naphtali Herz Weisel (also known as Hartwig Wessely, 1725-1805) published his treatise Divrey Shalom ve-Emet [Words of Peace and Truth], which he dedicated "to the entire Jewish nation, [but] especially to those living under the protection of the glorious and mighty emperor Joseph II" (Weisel 1781/1782; Wessely 17821; Mendes-Flohr and Reinharz 1995). Weisel's contested tract on the reform of Jewish education was a reaction to the imperial circular published by Joseph II in May 1781 (for an analysis of Weisel's tract cf. (Kieval 1987, pp. 83-84; Hecht 2004, pp. 118-19; Pribram 1918)), where the emperor had announced his intention to issue new edicts for the Jewish subjects of the Habsburg Monarchy and outlined a series of measures he intended to take, in order to make Jews "more useful to the state." This prompted Weisel to praise Joseph II and the expected reforms in quasi-messianic terms:

And so now, perhaps the time has come to remove hatred from the hearts of men [...]. O Generation! You have seen that God is good. He has raised up a great man, a savior to mankind, the exalted emperor, His Majesty Joseph II. [ . . . In] his many good works he has not forgotten a poor people, long abused, the Jews. He gave us many good and consoling commands, as a father does to his son, a teacher to his pupil and a [benign] ruler to his people. He has unshackled the disabling bonds by permitting the Jews to engage in all forms of cultivation of the land, to work in all crafts and to deal in all merchandise. [...He] has commanded us upon a righteous path (Mendes-Flohr and Reinharz 1995, pp. 73-74).

Due to their centuries-long oppression and the occupational restrictions placed on them, Jews had-understandably enough—lost interest in secular knowledge, Weisel explained further. But now

1 This text appeared in German translation as Wessely, Hartwig. 
that the humane legislation of Joseph II (1780-1790) had opened the gates of the ghettos and removed all differences between Jews and Gentiles, Jews should grab the chance to provide their children with a thorough education in Jewish and secular subjects. By doing so, they would overcome the dichotomy between Jewish and gentile society that had characterized Jewish history for the past few centuries. The parallel reform and evolution of Jewish and secular education was one of the main tenets of the Jewish Enlightenment, the Haskalah. The harmonic integration of Jewish subjects in the general school curriculum (or vice versa) symbolized the convergence of Jewish and gentile society. On the face of it, Joseph's imperial circular certainly conveyed the impression of being an important move toward Weisel's aim of an integrated education and toward the civil emancipation of Habsburg Jews in general. The circular emphasized the blessings of secular education that should be made available to Jews and listed a variety of professions that Jews might practice henceforth (Pribram 1918). Reality was somewhat different though. In the last paragraph of the circular, Joseph II remarked that his suggestions should be discussed by the relevant administrative bodies in the Monarchy's different provinces, the Länderstellen. The latter should adapt his proposals and harmonize them with the local laws and necessities (Pribram 1918, p. 441).

Joseph II's so-called Edicts of Toleration (Hecht 2015b, p. 138) for Habsburg Jews seemingly pursued the unification of the legal status of Jews in different provinces, as part of the bureaucracy's rationalizing and centralizing processes. But as a result of the adaptations made by the different Länderstellen, most particularities of the individual Judenordnungen (legislation for Jews) remained untouched by the new legislation and painful restrictions persisted until the revolution of 1848, some even until 1867. Nevertheless, the Edicts were enthusiastically welcomed by the upper echelons of acculturated Jewish society in the Habsburg Monarchy, who regarded them as the first step toward full legal emancipation.

This assessment was encouraged by the ideological underpinnings of Joseph II's Edicts, which were aimed at the acculturation of Jews. Hence, Joseph II ordered the establishment of secular Jewish schools, where Jewish children should learn to read and write in the Landessprache (lit. language of the land, i.e., national language; in fact, German) and get acquainted with basics in the sciences and humanities. Additionally, Jews were granted the right to enroll in Christian institutions of higher education and to pursue university degrees. While mainly interested in educating useful citizens, the state instigated thorough changes in Jewish society. Many Jewish families seized the opportunity for upward social mobility, and an increasing number of Jews graduated from universities from the second decade of the nineteenth century onward.

The extension of Maria Theresa's law for compulsory primary schooling from 1774 to the Jewish population by Joseph II was indeed a cornerstone of the 'Edicts of Toleration' that were issued for the different provinces between 1781 and 1789 (Hecht 2015b; Silber n.d.) ${ }^{2}$. Due to the interventions of the Länderstellen, the Edicts differed considerably in each province and many features of the old Judenordnungen remained untouched; for instance, restrictions on settlement that banned Jews from many prospering cities and regions, constraints on the freedom of movement, as well as limitations in many professions, especially in state administration and professions that were organized in guilds. In the Bohemian lands, the so-called Familianten laws from 1726 that allowed only for the eldest son to legally marry and to establish a family remained in effect until 1848 (Kestenberg-Gladstein 1969, pp. 1-3, 34-40). The establishment of more than 200 secular, state-supervised primary schools for Jewish children during the reign of Joseph II, on the other hand, could be seen as a huge success in the cultural, pedagogic and social arena (Hecht 2014; Hecht n.d., "Normalschulen") 3 .

The successful establishment of the schools, however, depended on an agreement between state authorities and traditional Jewish elites. Therefore, state authorities granted the radical

\footnotetext{
On the Edicts and their intentions cf. (Silber n.d.b, "Josephinian Reforms").

For an English summary cf. (Hecht n.d., "Normalschulen").
} 
segregation between religious and secular subjects. Only the latter were taught in the state-controlled German-Jewish schools, whereas the religious subjects were studied without major changes at traditional Jewish institutions (Hadarim and Yeshivot) under the supervision of traditional Jewish elites. This compromise satisfied the traditional segments within Jewish society, but it thwarted the pedagogic ideas of the Maskilim (Jewish Enlighteners), who sought to integrate secular and (religious) Jewish subjects, as expounded above. While some Maskilim from the German lands were, understandably enough, disappointed with this "Austrian solution," their peers from the Habsburg Monarchy, nevertheless, praised the emperor as "the crowned humanist" who through his Edicts of Toleration "removed the yoke that had chafed the Jews' soul and body" for centuries (Hecht 20084; Beer 1839). Although most of the restrictions remained, an essential feature of the Edicts was to 'restore the Jews to their dignity', as many contemporaries perceived it. In addition to the establishment of secular Jewish schools, Joseph's gestures were of tremendous symbolic importance, since they contained the promise of acceptance and integration. Jews were no longer obligated to pay the degrading body tax (assessed on Jews and cattle), nor would they be required to display distinctive signs of social segregation, such as the yellow badge or the beard (Hecht 2004). Therefore, the upper echelons of acculturated Jewish society enthusiastically welcomed the Edicts; but also more traditional segments of Habsburg's Jewry hoped for upward social mobility due to the possibilities available through the newly established educational system. The chief rabbi of Prague Ezekiel Landau (1713-1793), for instance, emphasized the practical value of secular education-notably thorough knowledge of the German language-that would help Jews to succeed in their enterprises (Landau 19665' Saperstein 1989, pp. 364-656).

Particularly in the Bohemian lands, the German-Jewish school system was a sweeping success, and even the most traditional parts of Jewish society participated in its achievements. Unlike Hungary, where the German-Jewish schools unceremoniously vanished after Joseph II's death and Galicia, where the much-hated school system was finally abolished in 1806 (Sadowsi 2010), the Bohemian and Moravian schools thrived and flourished for more than a hundred years (Hecht 2011a, pp. 168-75). Any study that focuses on the interplay between secular education and political involvement of Habsburg's Jewry during the first half of the nineteenth century should thus concentrate on the lands of the Bohemian crown. Compared to the Bohemian lands, the emergence of an unequivocally secular Jewish intelligentsia in Hungary and (even more so) in Galicia lagged slightly behind. Many of the Hungarian Jewish intellectuals who participated in the 1848 revolution, i.e., contemporaries and comrades-in-arms of our reference group, studied in a Yeshiva before delving into secular studies and journalism. ${ }^{7}$ Secular Jewish intellectuals from Galicia, like the physician and journalist Moritz Rappaport (1808-1880), on the other hand, were still a tiny minority without a major influence on the wider society before 1848 .

While the impact of the Josephinian school-system on the modernization and secularization of Habsburg Jewry has already been explored in various studies (Hecht 2004, pp. 118-19), the current article addresses the frustrations involved in the process. Education was certainly the driving force in the course of social and political integration of the Jewish population. But neither the reorganization of Jewish education nor the integration into majority society went along the harmonious lines envisioned by the Haskalah movement. Using a sample of Jewish intellectuals from the Bohemian lands, or more particularly Bohemia and Moravia, I will explore whether the high level of education combined with frustrated hopes for emancipation turned these young intellectuals into critics of the Monarchy and

4 E.g., Moses Mendelssohn reacted rather unenthusiastically to Ferdinand Kindermann's invitation to cooperate in the adaptation of text books for Jewish students, cf. (Hecht 2008).

Photo-offset of Warsaw, 1899 ed., fol. 53a-54a.

An English translation of (Landau 1966) can be found in Marc Saperstein.

Cf. e.g., Moritz Gottlieb Saphir, Moritz Bloch, Simon Szántó, Josef Szántó, Simon Bacher. 
supporters of the 1848 revolution; i.e., whether Joseph's 'Edicts of Toleration' had, unintentionally, generated a new group within Jewish society that was determined to fight for their rights.

The first generation of Bohemian and Moravian Jews after the publication of the 'Edicts of Toleration' mostly contented themselves with primary education. However, from the second decade of the nineteenth century onward we see a growing number of Jewish gymnasium and university graduates. Due to the still prevailing settlement restrictions that-with the notable exception of Prague-banned Jews from most cities in Bohemia and Moravia or at least severely hampered Jewish settlement there, many of these modern Jewish intellectuals came from small towns or even villages. In order to pursue higher education, they moved to Prague and subsequently to Vienna; some of them, especially Moravian Jews, skipped the first step-because of the geographic proximity to Vienna (rather than to Prague). After graduating from university, they expected to find suitable jobs in the big city. Contrary to their original expectations, these well-educated young Jews were confronted with countless occupational restrictions once they had finished their studies. In his book Languages of Community Hillel Kieval claimed that the group of young intellectuals from Bohemia, born between 1815 and 1822, "looked at politics as the arena in which both personal designs for advancement and more universal visions of progress might be achieved" (Kieval 2000). Their involvement in revolutionary politics should thus be seen as an inherent part of the exit from the ghetto and Jewish participation in gentile society. Despite this seemingly broad outlook, Kieval is mainly interested in the national makeup of the gentile society that would offer Jews the most favorable conditions for integration, i.e., in the question of whether these Jews joined the Czech or the German side in the national conflict. Analyzing the biographies of some intellectuals, he argued that, after a brief flirtation with Czech nationalism, these individuals returned to the fold of German culture that proved to be more inclusive and less anti-Semitic for the time being.

Margarita Pazi, on the other hand, explicitly linked the revolutionary impetus of Central European Jewish intellectuals to the withheld emancipation. In her article about the participation of Jews in the German National Assembly in Frankfurt of 1848-1849, she suggested that by promoting the comprehensive secular education of Jews, the Habsburg Monarchy had laid the groundwork for the revolutionary involvement of Jews in the German National Assembly (Pazi 1976, pp. 176-77). She substantiated her claim by scrutinizing the political affiliation of the Jewish participants in this council; of 565 participants, sixteen were Jews (by descent or religion); five of them can be associated with the political right and eleven with the left or radical left. The leaning toward political radicalism becomes even more palpable, when Pazi differentiates between Jewish descent, i.e., Jews who had converted to Christianity previously, and Jews by religion; of the latter only one can be counted amongst the right-winged factions, whereas the rest supported radical ideas of change (Pazi 1976, p. 185). Notwithstanding the overt connection to the Edicts of Joseph II, which Pazi quoted in the beginning of her article as the most prominent case of suspended emancipation, only five of the sixteen people presented in her article came from the Habsburg Monarchy, but four of the latter from Bohemia.

However, it seems worthwhile to pursue Pazi's argument further. As described above, many Jews, especially the more educated and acculturated segments of Jewish society, perceived the Josephinian edicts as a promise of or the first step toward imminent emancipation. Therefore, they enthusiastically participated in the Napoleonic Wars and shared the patriotism of their non-Jewish peers (Beer 1815) ${ }^{8}$. Michael Silber argued that as early as 1789 the patriotic fervor displayed in actions and writings of Habsburg Jews from all camps struck a new cord; it exceeded the customary Jewish loyalty toward the ruling régime, since it was based on the "logic of citizenship" rather than on the old clientele politics (Silber 2004, pp. 30-31) ${ }^{9}$. Silber's conclusions are based on his analysis of the ideological turns and

8 For a demonstration of Jewish patriotism during the Napoleonic Wars cf. e.g., (Beer 1815).

9 Silber stated that the Galician patent from 1789, which contained the most comprehensive degree of equality, caused traditional as well as progressive circles among the Jewish population to agree to military conscription. Indeed it instilled "the logic of citizenship with its rights and obligations" in Habsburg Jewry, cf. (Silber 2004, pp. 30-31). 
changes under the reign of Joseph II and its aftermath. However, it seems that in the long run the combination of a high level of education, limited opportunities in the professional sphere and withheld emancipation undermined the faith of intellectuals in the Habsburgs' capacity to rule.

Extending Pazi's claims, I would like to explore whether the combination of academic education and frustrated hopes for emancipation turned young Jewish intellectuals into critics of the Monarchy and radical supporters of the 1848 revolution. Contrary to Pazi and Kieval, I am interested neither in actual politics nor in nationalist affiliations, but in the mere process of integration. The question of Czech, German or Jewish nationalism certainly represents a fascinating vantage point for the analysis of these Jewish intellectuals. The national approach has been favored by many central European (especially Czech) scholars, partly in an apologetic and partly in a critical sense. My approach, on the other hand, links education and social criticism from the perspective of a minority group that asks to reap the fruit of unconditional and far-reaching acculturation. Since minorities tend to form subcultures when incorporating into majority societies (Volkov 1990) ${ }^{10}$, I shall concentrate on groups and personal networks rather than on pioneers and isolated individuals. These networks formed around a couple of journals that advocated new aesthetic concepts and eventually also revolutionary social and political ideas. Similar to their Enlightenment predecessors, the revolutionary Jewish intellectuals constituted a close-knit 'Republic of Letters' that shall be traced through the first half of the nineteenth century.

For various reasons, Vienna presents the prefect focus for this venture. As the capital of an empire it offered ample economic and cultural possibilities for aspiring youngsters. However, Jewish life in the city remained precarious until the 1850s. After the second expulsion from Vienna in 1670, only individual Jews were re-admitted to the city, and were subject to a considerable tax (Toleranzsteuer). The application for residence had to be renewed every year and could not be passed on in the family. As a consequence, only 66 tolerated Jewish families and their employees (approximately 500 people) lived in the city in 1780; they were not allowed to form a community or hold public religious services. Joseph II's Edicts hardly changed this legal situation (Wolf 1861). Nevertheless, the Jewish presence in the city slowly increased. Although it was difficult to obtain a permit of residence, aspiring intellectuals from the provinces had mainly two possibilities to acquire an 'entrance ticket' to the capital: they could enroll at the university (which granted a permit for the duration of studies) or take on a job as a private tutor in the service of a tolerated family (Gasser 2010) ${ }^{11}$. Moreover, the absence of an official and organized Jewish community implied that young (secular) intellectuals hardly faced surveillance by Jewish religious elites, as it was still the case in established Jewish communities, especially in Moravia.

In order to state my case, I have chosen a cohort of Jewish intellectuals who came from the Bohemian lands (i.e., Bohemia and Moravia), most of them from the provinces. They were born roughly between 1810 and 1820, "the youth of the 1840s", as Moritz Hartmann's biographer Otto Wittner had called them (Wittner 1911). They were educated in a "nanny state" that was a legacy of Joseph II's enlightened absolutism, alas "without the spirit of enlightenment" (Wittner 1911). They were all writers and journalists and/or editors for and of non-Jewish journals in the Vormärz period, i.e., the decades preceding the 1848 revolution. Despite oppressive censorship laws that hampered intellectual life in the Habsburg capital, most of them lived in Vienna for a substantial period of their life. They adhered to social liberalism and did not want to be confined to the "Jewish ghetto". Nevertheless, they were in several ways attached to Jewish tradition and in general cherished their Jewish identity/ies. Although coming from different geographic, socio-economic and religious backgrounds, they considered themselves as part of the German Bildungsbürgertum (Kaplan 1991) ${ }^{12}$ and were thus connected through their commitment to German culture and liberal values alike.

10 For the German context of the 19th century this nexus has been aptly analyzed by (Volkov 1990).

11 Cf. for instance Benjamin Kewall who came to Vienna from Polna around 1847 and was employed as a tutor by the family of Markus Mayer Strass, Others combined the tutor job with their university studies, as e.g., Ludwig August Frankl, cf. (Laß 1963, p. 343).

12 On the values of the Jewish middle class (although discussed in the context of the German Kaiserreich) cf. (Kaplan 1991). 
German literary traditions strongly influenced the young writers and some of them temporarily moved to German cities (especially to Leipzig) to escape Habsburg censorship regulations. These 'censorship refugees' instigated a cultural exchange within the German lands, but also stimulated literary production in the Habsburg Monarchy (Wittner 1911, p. xii). The younger part of the group strongly identified with the social and cultural ideas of the Czech national movement during the $1830 \mathrm{~s}$ and early 1840s, in particular with a romantic notion of Czech folk culture and history; but they were critical or even hostile toward the Russophile leanings of the Czechs (Donath 1934) ${ }^{13}$, especially, but not exclusively, during the 1848 revolution (Pazi 1973 ${ }^{14}$; Riff $1983^{15}$ ). In contrast to their gentile peers, the young Jewish intellectuals did not perceive the Russian Empire primarily as a sponsor of Slavic culture; for them, the image of Russia was tainted by the undemocratic nature of the state and the suppression of the Jewish population in the Russian Empire. Because of their general opposition to the oppressive and elitist political systems of the Vormärz period, they were strongly committed to social justice. Some of them even subscribed to socialist ideas. They were partly inspired and partly appalled by Prague's reality. Due to the many textile factories in the city, the Bohemian capital became the scene of the first violent clashes between capitalists and the rising proletarian population in the 1840s. The protest movement expressed itself through demonstrations and machine-breaking, but also by plundering of the Jewish Ghetto and personal attacks against Jews (Wittner 1911, p. xvii; Niedhammer $2013^{16}$ ).

The group was linked through personal friendship. They belonged to the same social and literary circles, exchanged numerous letters and published in each other's journals, i.e., they formed a close-knit intellectual network. Otto Wittner already suggested in 1911 that editing and analyzing the abundant correspondence of this generation would allow one to write a comprehensive cultural history of the time (Wittner 1911). They all graduated from gymnasium and most of them also from university. A disproportionate number studied medicine, although, with the exception of Siegfried Kapper, none of them ever worked in the medical profession. To the present day, medical school is the gateway for upward social mobility of minorities. Thus, the choice of this field of study was apparently part of the integration process. Nevertheless, it also points to a lack of opportunities, as Ludwig August Frankl, an older member of the group, illustrated in his memoirs. During an audience with Crown Prince Ferdinand I (Emperor 1835-1848), to whom Frankl had dedicated his first book on a patriotic topic, the crown prince suggested that Frankl should study history rather than medicine and become a university professor; whereupon the latter tauntingly replied that a Jew cannot become a professor in Austria. At that, the crown prince advised him to continue his medical studies and to write in his spare time (Frankl 1910, pp. 165-66).

Part of the group, namely Moritz Hartmann, Siegfried Kapper and Leopold Kompert, started their studies in Prague almost simultaneously and belonged to a literary circle that had adopted the name "Young Bohemia"17. However, they all moved to Vienna in order to finish their degree and/or to enjoy the cultural opportunities of the imperial capital. For all of them, frequent migration within the Habsburg Monarchy and beyond became part of their intellectual and Jewish persona. They actively participated in the 1848 revolution in one of the big cities of the Empire, i.e., in Vienna, Prague or Preßburg/Poszony (today Bratislava). They rallied for democratic rights and a constitution that would

13 The only exception might be Siegfried Kapper, who, according to his biographer Oskar Donath, considered "becoming a teacher in Russia" during his studies; however, he never made it to Russian soil, cf. (Donath 1934). This piece includes a selection of Kapper's letter and two autobiographical sketches.

14 The pro-Russian and anti-German statements of the Czech journalist Karel Havlíček Borovský (1821-1856) during the 1848 revolution ended the cooperation between Czechs and Germans in the Národní Vybor (National Committee) in Prague, cf. (Pazi 1973, pp. 242-43).

15 However, Moritz Hartmann already expressed strong opposition to Russia and the Czech-Russian connection during the anti-Jewish pogroms of 1844 in Prague, cf. (Riff 1983, pp. 68-70).

16 On the anti-Jewish attacks cf. (Niedhammer 2013).

17 The name is a deliberate allusion to "Young Germany", a group of progressive German literati during the 1830s that included the converted Jews Heinrich Heine and Ludwig Börne. 
enfranchise the masses but also include the legal emancipation of Jews, freedom of the press and German national unity, albeit under the leadership of the Habsburgs/Austria. Moritz Hartmann and Ignaz Kuranda were even elected as representatives to the German National Assembly in Frankfurt. The suppression of the revolution and the neo-absolutist regime that followed became a decisive turning point in their lives.

Many of these revolutionary Jewish intellectuals have been treated individually (or in pairs) in various contexts by modern scholarship; but except for a PhD thesis on Moritz Hartmann from the 1960s (Laß 1963) and the recently published collective biography on Ludwig August Frankl (Hecht 2016c), none of them was deemed worthy of a book-length biographical study by contemporary scholars. ${ }^{18}$ On Hartmann, Kapper and Kompert there are extensive studies from around 1900 though, that still serve as the basis for most modern analyses. Some people from my cluster, namely Moritz Hartmann, Siegfried Kapper and Leopold Kompert, have been discussed together by Hillel Kieval, in the context of Czech nationalism and the first cautious rapprochement between Czechs and Jews during the 1840s (Kieval 2000, chp. 3). The group, however, has never been discussed together, combining the aspect of education and withheld emancipation. Although the reference group is rather small, ${ }^{19}$ it still allows us to highlight some characteristics of the emerging modern Jewish intellectuals in the Habsburg Monarchy.

The most senior member of the cluster, and therefore also the focus of the group of Jewish intellectuals in Vienna, was Ludwig August Frankl (1810-1894). Frankl was born in 1810 into a well-connected bourgeois Jewish family of tobacco leaseholders who obtained a special license to settle in the small town of Chrast, next to the district town Chrudim, in Northern Bohemia. Jews were normally not allowed to live there; thus, the place lacked Jewish facilities, e.g., a Jewish primary school (for Frankl's biography, see (Hecht 2016a, “A Biographical Sketch"20)). After visiting the Christian Czech language elementary school in his hometown, Frankl attended the gymnasiums of Prague and Litomyšl/Leitomischl. Thereafter he moved to Vienna to study medicine, although he would have preferred to study humanities (cf. Ludwig Frankl's above-mentioned comment on his field of study, (Frankl 1910, pp. 165-66)). He finished his degree in Padua in 1837, but never practiced as a physician. He only considered making use of his original training when state authorities threatened to expel him from Vienna in the aftermath of the 1848 revolution (Wienbibliothek, Nachlass Ludwig August Frankl ZP H7-F7). Already during his gymnasium years, he successfully engaged in writing literature. Some of his publications won him prestigious awards and honors while still young. The most impressive among them was a golden tobacco tin from the above-mentioned crown prince Ferdinand I as a reward for his collection of patriotic ballads entitled Das Habsburglied (1832). ${ }^{21}$ Like many youngsters, in his youth Frankl was attracted to powerful and heroic figures that changed the course of history. The orientation toward historical motifs and Bohemian folk tales (Frankl 1828 ${ }^{21}$; Petrbok $2016^{23}$ ) can arguably be attributed to the romantic influence of the Czech National Revival that sought to create a Czech 'subculture' by reinforcing the image of folk heroes (Macura 1998) ${ }^{24}$. At this stage of his life, Frankl employed biblical imagery (Frankl 1836) ${ }^{25}$, but beyond that he did not consider Jewish topics appealing; (post-biblical) Jewish history seemed too particularistic and clashed with his cosmopolitan sensibilities (Hecht 2014) ${ }^{26}$.

However, there are several studies that analyze the literary output of Frankl, Hartmann and Kompert.

9 There are a couple of individuals at the fringes of the circle portrayed here that have been excluded, because they were connected only to specific members of the network, e.g., Isidor Heller, David Kuh and Max Schlesinger, and/or had a different geographic focus, as Isidor Busch, who migrated to the USA in 1848.

20 On Frankl's biography, cf. (Hecht 2016a).

21 Cf. Report about the event in (Wiener Zeitung 1832, p. 173).

21 His first publication for example was dedicated to the Bohemian "Robin Hood" Jan Pancír.

23 For an analysis of Frankl's heroic motifs, cf. (Petrbok 2016, pp. 102-6).

24 On the Czech national movement around 1800, cf. (Macura 1998).

25 E.g., by comparing Columbus to Moses, cf. (Frankl 1836).

26 On Frankl's cosmopolitanism cf. (Hecht 2014). 
Nevertheless, Frankl accepted the position as secretary of Vienna's Jewry, after graduating from university in 1838. This allowed him to receive a permit of residence for the capital and to make a living at the same time. Until 1848, Ashkenazi Jews were not allowed to reside in Vienna, unless they paid a high toleration tax or were employed by tolerated Jews (Hecht 2015b, p. 138) ${ }^{27}$. However, Frankl never limited himself to the Jewish sphere. He became known to the Viennese public as a journalist and editor of the Sonntagsblätter. This cultural and literary weekly first appeared in Vienna in January 1842 and soon became prestigious because of the prominent writers Frankl recruited for his journal. Furthermore, it served as a forum for many promising young writers until its suppression in October 1848 (Dollar 1932) ${ }^{28}$. Frankl intentionally published the works of Jewish and Christian writers side by side. For many young Jewish writers from Frankl's native Bohemia the Sonntagsblätter became their stepping stone in the world of German letters (Riff 1983, p. 62). The most prominent between them were Moritz Hartmann (1821-1872), Siegfried Kapper (1821-1879) and Leopold Kompert (1822-1886) who had already formed a literary circle during their early student years in Prague.

Frankl greeted the outbreak of the revolution enthusiastically. On 19 March 1848, he opened his paper with the following words: "I have been editing the Sonntagsblätter for 6 years and $2 \frac{1}{2}$ months now, releasing 322 issues thereof. Herewith, I declare them all null and void, and start from today with no. 1" (Sonntagsblätter 1848, p. 127). From this date on, the Sonntagsblätter decidedly changed its content and turned from a literary journal into a mouthpiece of the revolution. Frankl's involvement with the revolution eventually led to the paper's suppression by state authorities on 22 October 1848 . Like other Bohemian Jews, Frankl was threatened with expulsion from Vienna for his contacts with radical elements. Only his connections to high-ranking politicians and the intervention of the Jewish community spared Frankl the fate of his less fortunate fellow Jews (Wienbibliothek, Nachlass Ludwig August Frankl ZP H7-F7). After the Sonntagsblätter was forcefully shut down, Frankl had to renounce political topics and increasingly turned to Jewish themes. It seems that Frankl primarily drew upon his Jewish networks, when being rejected and/or restricted by gentile society, just as in the case of his employment as secretary of Vienna's Jewry. Like most members of his peer group, he became a respected citizen and an ardent Habsburg patriot in the constitutional era after 1867. For his manifold achievements for Austrian culture he was even ennobled in 1876 and adopted the title of nobility "von Hochwart" (Hecht 2016b, p. 306, "Durch Wort und Tat").

The one most dedicated to social radicalism among this group was probably Moritz Hartmann (1821-1872) (Bourke 2001) ${ }^{29}$. Hartmann was born in Dušníky/Duschnik (North Western Bohemia) to a well-to-do Jewish family and seems to have received mainly private tutoring during his elementary school years (Wittner 1903). After visiting the Altstädter gymnasium in Prague for one year, he came to Mladá Boleslav/Jungbunzlau in 1833, where his grandfather Yom Tov/Isaac Spitz, son-in-law of the venerated Prague rabbi Elazar Flekeles, served as a rabbi from 1824-1842. In this town he visited the Piarist gymnasium for five years, together with Leopold Kompert (Wittner 1906). The young students also associated with Isidor Heller (1816-1879), a native of Mladá Boleslav, who introduced the inquisitive boys to modern German literature, especially to the authors of "Young Germany" (Wittner 1906, pp. 14-15). From 1838 onward, Hartmann enrolled in the philosophical classes at the University of Prague, as a preparation for medical studies. He socialized with a group of Jewish and non-Jewish intellectuals; this group included Isidor Heller, who had also moved to Prague, Siegfried Kapper, Friedrich Hirschl (1822-1882), who later magyarized his name to Szarvady Frigyes, and Leopold Kompert, as well as the non-Jews Alfred Meißner (1822-1885) and Friedrich Bach

27 The somewhat misleading term Edicts of Toleration (Toleranzpatente) was borrowed from the edicts which Joseph II issued in 1781-1782 for non-Catholic Christians in the Monarchy, i.e., Lutherans, Calvinists and Greek-Orthodox, who previously did not enjoy freedom of religion. Contrary to the latter, Jewish religion and religious praxis was accepted wherever Jews were allowed to settle. For convenience, the term will be retained, but put in quotation marks.

28 Frankl's journalistic enterprise is newly appraised in a Ph.D. thesis prepared at the University of Vienna Department of Journalism.

29 On Hartmann's social radicalism cf. (Bourke 2001, pp. 427-28). 
(1817-1865). They were regulars of a pub called Roter Turm in Prague's Zeltnergasse/Celetná and adopted the name "Young Bohemia" as a tribute to their German role models (Kieval 2000, p. 72). Most of them remained Hartmann's friends for life (Hartmann's extensive correspondence is partly edited, cf. (Wittner 1911; Wolkan 1921) ${ }^{30}$. Hartmann made his literary debut in Rudolf Glaser's journal Ost und West: Blätter für Kunst und geselliges Leben (1837-1848) that sought to promote Slavic culture amongst German readers (Wittner 1906, pp. 30-31). While the non-Jews Meißner, Bach and Glaser were essential contacts in the world of letters, it is striking that the majority of Hartmann's circle were fellow Jews.

After repeatedly failing his exams, which according to his biographer Wittner should be mainly attributed to the oppressive academic system in Prague (Wittner 1906, p. 37), Hartmann left Prague and the university. In 1840, he moved to Vienna where he became a private tutor for prosperous Jewish families, first in the house of Wertheimstein and later in the Lieben family (Wittner 1906, pp. 71, 103). Frankl introduced him to the literary circles of the capital and he started publishing in numerous journals, particularly in Frankl's Sonntagsblätter (Hartmann 1843, p. 1142) ${ }^{31}$. This demonstrates that Hartmann continued relying on his Jewish networks upon his relocation to Vienna. Furthermore, he befriended the radical revolutionaries Hermann Jellinek (1822-1848) and Alfred Julius Becher (1803-1848) (Wittner 1906, p. 101), who were both executed after the failed revolution in Vienna. In 1844 he left Vienna for Leipzig, where he published his first volume of poems Kelch und Schwert (Chalice and Sword, 1845). Like Frankl's first writings, it dealt with Czech history. Since it glorified the Hussites, it was banned in the Habsburg Monarchy. The political persecution caused Hartmann to move from place to place, but it additionally contributed to the author's fame. Following a stay in different German cities (repeatedly in Leipzig) and in Paris, Hartmann returned to Prague, where he witnessed the 1848 revolution and the attacks against Jews. He was elected as a delegate from the town of Leitmeritz/Litomerrice to the German National Assembly in Frankfurt, where he associated with the far left (Donnersberg). Together with Robert Blum (1807-1848) and Julius Fröbel (1805-1893), he went to Vienna in order to support the October uprising (Pazi 1973, pp. 245-53). Upon the suppression of the revolution, Blum was executed and Fröbel imprisoned, but Hartmann managed to escape. In the subsequent years, he travelled throughout Europe and successfully edited several journals. Hartmann was distressed by the Habsburg defeat at Königgrätz in 1866 and the subsequent unification of Germany under Prussian auspices. He would not renounce his vision of Greater Germany that included the Habsburg territories of the former Holy Roman Empire (Wandruszka 1980) ${ }^{32}$. In 1867, he took advantage of the amnesty granted to him and accepted the editorship of the Neue Freie Presse in Vienna that became the focal point for (Jewish) liberals in the constitutional era.

In poor health, he died on 13 May 1872 and was buried on Vienna's Jewish cemetery (Währinger Friedhof) (Central Archives for the History of the Jewish People 194133; Steines 1993). His burial place defies repeated assertions that Hartmann had converted to Christianity (typically stated without archival reference), but unlike most other individuals discussed in this sample, he rarely touched Jewish topics in his poems and stories (Kestenberg-Gladstein 2002) ${ }^{34}$. Despite his obvious distance to Jewish topics in his political and literary aspirations, he remained embedded in the Jewish social networks that he had forged in his youth.

30 Many originals as well as manuscripts of Hartmann's works (in total about 2500 items) are kept in the Wienbibliothek, Nachlass Moritz Hartmann.

31 Cf. the publication of Hartmann's poems e.g., (Hartmann 1843, p. 1142). The Sonntagsblätter also announced Hartmann's further publications.

32 It included the Austrian hereditary lands and the lands of the Bohemian crown; it excluded Galicia and the Hungarian part of the Habsburg Empire, cf. (Wandruszka 1980).

33 Part of Währinger Friedhof was destroyed by the Nazis in 1941-1942. Hartmann's grave was amongst those transferred to Vienna's Zentralfriedhof (Gate IV) in 1941, cf. (Central Archives for the History of the Jewish People 1941, A/W 1515).

34 On the Jewish aspects of Hartmann's writings cf. (Kestenberg-Gladstein 2002). 
Leopold Kompert (1822-1886), Hartmann's friend from his school days, was born in the small Bohemian town Münchengrätz/Mnichovo Hradiště (Hock 1906) ${ }^{35}$. He was certainly the most accomplished writer amongst the group discussed here and the one most inclined towards Jewish topics (Hess 2010) ${ }^{36}$. With his 1848 volume Aus dem Ghetto: Geschichten (From the Ghetto: Novellas) (Kompert 1848a), Kompert can be considered as the founder, or at least the most important representative, of ghetto fiction in German literature (Gollance 2017) ${ }^{37}$.

In his book on middlebrow literature, Jonathan Hess claimed that Kompert's main achievement is to be seen in the cultural capital the genre provided to Central European Jewry (Hess 2010). Since Kompert's literary production was not restricted to a Jewish audience, and enjoyed great prestige in the German literary world, he/it provided German Jews with cultural respectability that secured their middle-class status (Hess 2010, p. 80). Like the other group members, Kompert's main sphere of activity was German culture. By writing ghetto stories for non-Jews, he left the Jewish (cultural) ghetto and also helped his co-religionists to do so.

From 1832-1836, Kompert attended the Piarist gymnasium of Mladá Boleslav/Jungbunzlau, near his hometown, where he became friends with Moritz Hartmann. He finished gymnasium in Prague and was enrolled in the philosophical classes at the University of Prague until 1838. For the following two years he stayed in Vienna and earned his residence permit and livelihood as a private tutor for an affluent Jewish family. In 1840 he moved to Hungary; there he started writing for Adolf Neustadt's Preßburger Zeitung and its literary supplement Pannonia. Neustadt also introduced Kompert to Frankl who made Kompert known to the Viennese public by publishing Kompert's travel features from Hungary (cf. e.g., (Kompert 1842, pp. 433-39; Kompert 1845, pp. 1150-56)) in the Sonntagsblätter. Frankl also printed Kompert's first stories on Jewish topics in his Viennese journal; in 1846 descriptions "from the Ghetto" appeared in the Sonntagsblätter (cf. e.g., (Kompert 1846a, pp. 149-54; Kompert 1846b, pp. 513-15) and in 1848, shortly before the outbreak of the revolution, the Sonntagsblätter published one of Kompert's ghetto stories (Kompert 1848b, pp. 7-8), as a preview and advertisement for Kompert's book of ghetto fiction that was issued in Leipzig the same year.

Between 1843 and 1847, Kompert worked as a private tutor for Count Andrássy's children in Hungary. In 1847 he returned to Vienna to study medicine, but renounced his studies at the outbreak of the revolution. Like all his friends, Kompert was enthused by the revolution and its prospects of democratic freedom and Jewish emancipation. He also acknowledged its bleak sides though. After the anti-Jewish pogroms in Preßburg/Poszony (today Bratislava) in April 1848, Kompert was bitterly disappointed and seemingly abandoned the hopes he had once placed in European culture. He published his appeal "Auf nach Amerika" (On to America) in the Jewish weekly Oesterreichisches Centralorgan für Glaubensfreiheit, Cultur, Geschichte und Literatur der Juden (Austria's Central Organ for the Freedom of Religion, Culture, History and Literature of the Jews) (Hecht 2016d) ${ }^{38}$. There he urged his fellow Jews to seek freedom in the New World instead of struggling with European prejudices. However, Kompert defied his own appeal and stayed in Vienna. In 1857 he married Marie Pollak (née Löwy), the widow of Frankl's cousin Ludwig Pollak (1805-1848), and thereby also forged family ties to his (former) supporter. In the constitutional era, he became a celebrated writer and journalist and a respected member of society-Jewish as well as Christian.

Siegfried (Salomon) Kapper (1820-1879) was acclaimed by the Czech-Jewish movement in the first Czechoslovak Republic as a pioneer of their visions. Indeed, Kapper was the most dedicated amongst the group of young intellectuals that sought to promote the Czech-Jewish literary and cultural cooperation during the 1840s. All authors discussed so far were drawn toward the Czech national revival and contributed to Glaser's above-mentioned journal Ost und West that aspired to disseminate

35 Cf. unpublished letters by Kompert and his wife Marie Kompert/Pollak in the Wienbibliothek.

36 There are numerous studies that analyze Kompert's literary output. The most recent one in English is Jonathan M. Hess.

37 For a recent analysis of Kompert's ghetto fiction, cf. (Gollance 2017, chp. 2).

38 On the journal, Kompert's article and the latter's role during the revolution cf. (Hecht 2016d). 
the knowledge of Slavic culture among German readers. The cultural project endorsed by Kapper, David Kuh (1819-1879) and their Christian counterpart Václav Bolemír Nebeský (1818-1882) went much further (Hecht 2009, pp. 43-44) ${ }^{39}$; they ventured to win the Jews over for the Czech national cause and to adopt the Czech instead of the German language and culture. In a well-orchestrated campaign published in April 1844 in Julius Fürst's Jewish weekly Der Orient (1840-1851), in Ludwig Philippson's Allgemeine Zeitung des Judenthums (1837-1922), and in the Czech-language weekly Kvĕty (1834-1847) they tried convincing Jews to support the Czech national cause and Czechs to respect Jews and their cultural heritage (Kieval 2000, pp. 76-89). While Kuh and Kompert withdrew from the Czech-Jewish cooperation after the anti-Jewish pogroms in Prague and Hartmann was appalled by Palacký's anti-German stance during the 1848 revolution, Kapper remained sympathetic to the Czech cause.

Kapper's educational background resembles that of Hartmann and Kompert (Donath 1912, 1934; Krejčí 1911). He was born in Smíchov, today a district of Prague, then a village next to Prague, in 1820. After attending elementary school, he entered gymnasium in Prague's Kleinseite/Malá Strana in 1830 and enrolled in the philosophical classes at the University of Prague in 1836. While originally interested in law, he decided to study medicine for practical reasons. To make a living, he took over Hartmann's job as a private tutor, when the latter left for Vienna. His first publications were translations of Czech and Slovak poems in Ost und West (1839) and of Ukrainian ballads in Frankl's Österreichisches Morgenblatt in the same year. ${ }^{40}$ In 1841 he moved to Vienna and became a regular in the cafés of Slavic students, where he met Václav Bolemír Nebeský. He also befriended the Serbian poet Vuk Stefanović Karadžić (1787-1864) and became interested in Serbian folk tales. At the same time, he started writing ghetto tales and published his first volume of poems-a mixture between translation, free adaptation and original poetry-that he dedicated to his patrons Karl Egon Ebert and Ludwig August Frankl (Kapper 1844), i.e., despite his empathy with Slavic culture he drew on the same networks as the other group members. Encouraged by Nebeský, he published a volume of Czech poetry two years later (Kapper 1846), where he expressed his love for his Czech homeland, but also advocated emancipation and the egalitarian treatment of Jews. A devastating review of this volume by the leading Czech journalist Karel Havlíček Borovský (1821-1856) arguably silenced Kapper's aspirations to write original poetry in Czech (Riff 1983, pp. 65-76).

In 1847 he finished his medical studies and worked as a physician in Karlstadt/Karlovac, Croatia until February 1848. Before the outbreak of the revolution, he returned to Vienna where he wrote for several journals and-together with Frankl—fought in the Akademische Legion (Academic Legion). He defined himself as an "attaché of the left" (Donath 1934, p. 349) and without any success tried to mediate between Czechs and Germans. After the suppression of the revolution in Vienna, he moved to Preßburg/Poszony to report about the revolutionary events in Hungary for Franz Klutschak's (1814-1886) Constitutionelles Blatt aus Böhmen, a revolutionary addendum to the long-lived Prague newspaper Bohemia (1830-1938). Since he had published most articles under pseudonyms, he was not overtly persecuted. However, he chose to travel on the Balkans for several years to evade possible repressions. In 1853 he opened a doctor's office in Dobř̌̌š/Doberschisch and a year later married Anna Hartmann (1835-??), the sister of his school-day friend Moritz Hartmann. Just as Kompert, he combined personal ties with his professional network. In 1860 the couple moved to Mladá Boleslav/Jungbunzlau and in 1867 to Prague, where he continued to work as a physician and was also active in respected Czech cultural institutions. Until his death in 1879 Kapper published numerous works in Czech and German.

Another focal point of young critical intellectuals was the journalist and politician Ignaz Kuranda (1811-1884), who belonged to Frankl's age group. He was born to a family of well-established

39 On Kuh's relationship to Czech culture cf. (Hecht 2009).

40 Frankl took over the editorship of this journal, before he established his own Sonntagsblätter in 1842. 
antiquarian booksellers in Prague. Little is known about Kuranda's childhood and education. He studied at the Piarist gymnasium in Prague Neustadt/Nové Město (Heuer 1992-2013, vol. 15, pp. 3-4.). Othmar Doublier claims that he had attended lectures on philosophy in Vienna in 1834 and Wolfgang Duchkowitsch asserts that he had studied German history and literature in Stuttgart and Tübingen in the late 1830s and held a PhD in philosophy from the University of Leipzig (Doublier 1906; Duchkowitsch 2014; Wistrich 1990; Bacher 1881) ${ }^{41}$. In 1834 he moved to Vienna and started writing theatre reviews and sketches. His first play Die letzte weiße Rose ("The Last White Rose," 1838) was written in a spa town next to Vienna, but at first was rejected by Viennese theaters (Schumacher 1844) ${ }^{42}$. It was staged instead in different German cities and Kuranda used this occasion to travel to Germany, from where he proceeded to Paris and Brussels. In the latter city, Kuranda launched the journal Die Grenzboten (The Frontier Messengers, 1841-1922) that originally sought to promote the cultural exchange between Belgium and Germany. For political reasons, the journal's editorial office moved to Leipzig in 1842, where censorship rules were more lenient. Thereafter, the journal turned into a platform for Habsburg subjects in exile or writers disagreeing with the government policy at home (Duchkowitsch 2014, pp. 137-47). It became a focal point for young intellectuals, who attacked the political system of Metternich and fought for the freedom of press, religion and science. The circle came to be known as "Young Austria"; it included Hartmann, Isidor Heller, Alfred Meißner and occasionally other writers of our sample. Kuranda secured that the ideological line of the journal would be critical, but not outright hostile toward the Habsburg Monarchy. He defined himself as "a passionate patriot, a faithful subject of the Kaiser, but also a man of progress and the opposition" (Duchkowitsch 2014, p. 142). With Kuranda's committed constitutionalism, the journal bridged the gap between the exiles and liberals within the Habsburg Monarchy.

In 1848, with the outbreak of the revolution in Vienna, Kuranda left Leipzig and the Grenzboten and returned to the imperial capital. He was promptly elected to the German National Assembly in Frankfurt, where he joined the radical left (Donnersberg), together with Hartmann. At the same time Kuranda established the Ostdeutsche Post (1848-1866) in Vienna. Since the journal presented an explicit pro-constitutional and pro-German orientation (Greater German Solution), it was suppressed between 26 October and 18 December 1848 as well as between 10 January and 6 February 1849. Kuranda had to step down from the editor's board in February 1849. As a 'foreign Jew' from Bohemia he had no right of residence in Vienna and was expelled to Prague in 1851. In 1853 Kuranda was allowed to return to Vienna and resumed editing the journal (Doublier 1906, pp. 448-49; Wistrich 1990, pp. 141-42; Szanto 1881, pp. 133-35). In the 1860s he became a representative in the Imperial Council and member of the City Council of Vienna; at the same time he was on the board of the recently acknowledged Jewish community of Vienna and later became its president.

A more flamboyant figure was the Prague born journalist Adolf Neustadt (1812-1875) (Silber n.d. ${ }^{43}$; Neustadt 1869). He was the son of the antiquarian bookseller David Neustadt, who changed his name to Neustadt during his sojourn in Hungary. His literary talent was encouraged by his teachers during his student years at the Piarist gymnasium in Prague, where he met Ignaz Kuranda. He also befriended Jewish and non-Jewish Prague intellectuals of his age, like Isaac Itzik Jeitteles $(1814-1857)^{44}$ and Franz Klutschak, the later editor of Bohemia, who would be part of his professional network for life. Soon he started publishing in Bohemia as well as in several papers in Vienna and Leipzig. In 1837 he was forced to leave his native city, allegedly owing to the publication of an

41 A peculiar source on Kuranda's biography is the short Hebrew sketch by Simon Bacher.

42 The play was an adaptation of a draft by Schiller; when the play was finally staged in Vienna's Court Theater, the Sonntagsblätter published a critical, but sympathetic review with a biographical sketch of Kuranda, cf. (Schumacher 1844 , pp. 1115-18).

43 Despite his importance during the Vormärz and 1848 revolution, there is little research literature on Neustadt (also Neustadtl) except for two extensive entries in encyclopedias. Cf. (Silber n.d.).

44 He later used the pseudonyms Julius Seidlitz, Ignaz Jeiteles and Julius Selt cf. (Heuer 1992-2013, vol. 13, pp. 50-53). 
incriminated book he had authored together with Jeitteles (Neustadt 1869, pp. 300-1; Seidlitz 1837). ${ }^{45}$ After a stint in Leipzig he moved to Vienna, where he became friends with Frankl and the renowned Hungarian journalist Moritz Gottlieb Saphir (1795-1858). He found work in the antiquarian bookshop of Franz Gräffer in editing the Österreichische National-Encyklopädie and additionally wrote as a foreign correspondent for various German papers. One of his articles in the Leipziger Allgemeine Zeitung led to a house search whereupon Neustadt left for Hungary in 1839.

In Hungary, he first wrote for Saphir's Tagblatt in Pest, but in 1840 he settled in Preßburg/Poszony and became the editor of the Preßburger Zeitung as well as its literary supplement Pannonia. He soon recruited prominent as well as aspiring writers and journalists (e.g., Leopold Kompert) and turned the provincial broadsheet into an internationally appreciated newspaper. He saw the outbreak of the 1848 revolution in Preßburg, where he joined the National Guard and actively recruited Jews for the revolutionary cause. Due to anti-Jewish riots in the city in April 1848 that were partly directed against his own person, he left Preßburg. He moved back to Vienna, started to write for Klutschak's Constitutionelles Blatt aus Böhmen and later edited the Jewish journal Wiener Blätter together with Meir Letteris (Hecht 2016d). Like Frankl and Kuranda, Neutsadt had no right of residence in Vienna. Because of his continuous political involvement, the police forced him to leave the city in the neo-absolutist era. After extensive travels in the Levant, he returned to Vienna 1854 and worked with/for Joseph Wertheimer (1800-1887), one of Vienna's most prominent philanthropists. Like Kuranda, Neustadt was co-opted onto the Viennese communal board in the constitutional era. In 1867 he married Rosalie Laur (1814-1890) from Breslau (today Wrocław) in Vienna's main synagogue (Archiv der Israelitischen Kultusgemeinde Wien 1867). During the last years of his life he was a board member of Vienna's Jewish community. He died in Vienna in 1875 and was buried in Vienna's Jewish Währinger Friedhof in the crypt of the venerated Wertheimer family (Archiv der Israelitischen Kultusgemeinde Wien 1875).

At the fringes of this illustrious circle we find the Moravian born Simon Deutsch (1822-1877), a rabbinical student from Nikolsburg/Mikulov (Archiv der Israelitischen Kultusgemeinde Wien 1822) ${ }^{46}$ Miller claims that Deutsch's Toleranzgesuch (request for residence in Vienna) from 1847 indicated that Deutsch had been born in Vienna, but fell under the jurisdiction of Nikolsburg, since his parents originated from there, cf. p. 389. However, there is no evidence in the birth records of Vienna's Jewry that Deutsch was born in Vienna, cf. (Kompert 1848b, pp. 7-8).. Apparently, he did not attend gymnasium, but as a rabbinical candidate he had to enroll in philosophical and pedagogical courses, i.e., the preparatory classes at the university, according to a Moravian law for the rabbinate from 1842 (Miller 2010, p. 380; Hecht 2004, pp. 118-19). Due to the lack of institutionalized secular education, his German language skills were obviously deficient; at least he seemed to have had a distinct (Jewish) accent. Deutsch moved to Vienna in 1844, but did not manage to establish himself as a journalist. ${ }^{47}$ He found a niche in organizing and analyzing the Hebrew manuscript collection of Vienna's Court Library and even issued a catalogue with descriptions of these manuscripts. Frankl supported him by announcing Deutsch's publications in his Sonntagsblätter ${ }^{48}$. In the first months of 1848, Simon Deutsch co-published a Jewish biographical compendium, together with the above-mentioned bookseller Franz Gräffer. The volume was entitled Jüdischer Plutarch and contained entries on 73 Jews (and former Jews) whom Deutsch considered worthy of entering the Jewish pantheon.

During the revolution, Deutsch joined the Akademische Legion (Academic Legion), which indicates that he had studied at the University of Vienna. Like a good part of this sample, Deutsch

45 Except for the entry on Neustadt in Wurzbach's Biographisches Lexikon, (Neustadt 1869, vol. 20, pp. 300-1) that was probably penned by Neustadt himself, Neustadt's co-authorship is never mentioned.

46 On Simon Deutsch cf. (Miller 2010, pp. 379-93).

47 The usually quoted "articles" in Sonntagsblätter and Der Orient are either announcements or reviews of his book publications.

48 For example, the edition of the dictionary of Menachem ben Saruq in (Sonntagsblätter 1845, p. 298); Beschreibung der hebräischen handschriftlichen Werke der k.k. Hofbibliothek, together with Albrecht Kraft. In (Krafft and Deutsch 1847, p. 16); Jüdischer Plutarch, together with Franz Gräffer. In (Deutsch and Gräffer 1847, p. 405). 
wrote for Der Radikale, the radically democratic paper of Alfred Julius Becher that appeared between June and October 1848. When the revolution in Vienna was crushed in October 1848, Deutsch had to flee Vienna, in order not to meet the fate of his friends Becher and Hermann Jellinek, who were court-martialed and executed. After a stint in Leipzig, he settled in Paris, where he associated with socialists, while doing successful business in the Ottoman Empire. In 1851 the French police suspected Deutsch and other émigrés from the Habsburg Monarchy, as for instance Sigmund Engländer, of being involved in a communist plot and sought to expel them (Miller 2010, p. 384). Already a year earlier, the reactionary Viennese journal Der österreichische Zuschauer (1836-1857) had published an article that ridiculed Jewish involvement in the 1848 revolution with a distinctly anti-Semitic tinge. Deutsch was portrayed as having metamorphosed from "ein kleiner Rabbiner" into "ein großer Jakobiner" (from a little rabbi into a big Jacobin) (Der österreichische Zuschauer: Zeitschrift für Kunst, Wissenschaft und geistiges Leben 1850$)^{49}$. However, Deutsch managed to stay in Paris and first visited Vienna only in September 1867 (Neue Freie Presse 1867, p. 15). He remained involved in the fight for democracy and social justice in the Habsburg Monarchy though his financing of the Österreichische Arbeiterbewegung (Austrian Workers Movement). In 1871 he supported the Parisian Communards and was temporarily imprisoned after the fall of the Commune. Ironically, he was released from prison thanks to the intervention of the Austrian ambassador to Paris, Prince Richard Clemens Metternich, son of the loathed Vormärz politician. Consequently, Deutsch was suspected to be a government agent and lost credibility in Austrian socialist circles (Miller 2010, p. 387).

Besides his backing of the socialist movement, Deutsch got involved with the New Ottomans (predecessors of the Young Turks) during the 1860s. This group of western oriented liberals, who partly lived in French exile, sought to introduce constitutional government in the Ottoman Empire to prevent its disintegration. In 1876 Deutsch's friend Midhat Pasha (1822-1883) was appointed Grand Vizier; not only did he initiate the first constitutional era in the Ottoman Empire, he also designated Deutsch as governor of Bulgaria. This did not escape the attention of the Viennese press. In January 1877 the popular Morgenpost (1850-1886) informed:

It is reported from there [Paris] that the well-known Simon Deutsch is designated as governor of Bulgaria. This banker, who is notorious in Vienna, seems to have gone through many metamorphoses and was converted from a Communard into a Young Turk. Nevertheless, he will hardly make it to 'Herrn Schouverneur' (Mister Jevernor) (Morgenpost 1877, p. 2).

Despite its anti-Semitic allusions, the Morgenpost was right in the end. Midhat Pasha was exiled in February 1877 and Deutsch died in Constantinople on 23 March 1877 (Neue Freie Presse 1877b, p. 5). His body was transferred to Paris and buried there in May 1877 (Neue Freie Presse 1877a, p. 1), probably next to his father ${ }^{50}$ (Neues Fremdenblatt 1863).

Another marginal figure in the tight-knit social network of our group was the journalist Sigmund Engländer (1820/1826-1902) (Häusler 1982). This is partly due to the fact that he was born and/or raised in Vienna and thus went through different patterns of socialization, but it is also due to his socialist radicalism and republicanism, which prevented him from returning to the Habsburg Monarchy in the liberal period, and perhaps his age, as he was younger than the others. Engländer was born in 1820 or 1826 (Häusler 1982, p. 85; Heuer 1992-2013, vol. 1, pp. 399-402) ${ }^{51}$, as the youngest son of Leontine (1782-1873) and Hermann Engländer (1779-1864) from Nikolsburg/Mikluov. ${ }^{52}$ After having

49 On personalities in the 1848 press, cf. (Der österreichische Zuschauer: Zeitschrift für Kunst, Wissenschaft und geistiges Leben 1850, pp. 996-1002).

50 Deutsch's father Joseph (1783-1863) had died in Paris cf. (Neues Fremdenblatt 1863, p. 3).

51 Heuer's Lexikon deutsch-jüdischer Autoren states 1828 as Engländer's birthdate, without any evidence. Cf. (Heuer 1992-2013).

52 The estate records of Hermann Engländer from 1864 affirm that Sigmund was 38 years old at his father's death, i.e., he must have been born in 1825/6, not 1828 as Heuer states. Cf. Wiener Stadt-und Landesarchiv A 6, Verlassenschaft, Hermann Engländer 21/1902. 
published a German prayer-book for women in 1824 (Engländer 1824; Hecht 2011b, pp. 168-75) ${ }^{53}$, his father Hermann Engländer moved to Vienna, where he established himself as a teacher and textbook writer. Additionally, he worked as a corrector for the prestigious Hebrew printing house of Anton Schmid ${ }^{54}$. After having attended Vienna's Schottengymnasium, the parents urged Sigmund to study law, which he did without any passion or success.

Already during his study years he started publishing in Frankl's Sonntagsblätter ${ }^{55}$ and became friends with many writers and poets, the most prominent amongst them being the playwright Friedrich Hebbel (1813-1863). In his diaries, Hebbel described the social and economic condition of the Engländer family as dire (Häusler 1982, p. 87). This might explain Engländer's inclination toward social reforms. As for most authors of this sample, Engländer's articles during the Vormärz-period were informed by a genuine concern for political and social injustice that repeatedly brought him into conflict with censorship laws. However, the lack of economic means as well as commitment to his family prevented him from leaving the city. In 1847 he founded his own journal, called Der Salon: Mittheilungen aus den Kreisen der Literatur, Kunst und des Lebens (The Salon: News from the Spheres of Literature, Art and Life) ${ }^{56}$ He managed to recruit celebrities like Hebbel, Bauernfeld and Frankl, as well as emerging authors like Kapper; he also asked Hartmann, Heller and Austria's 'national poet' Franz Grillparzer (1791-1872) for contributions. The journal was acknowledged as on a par with Frankl's Sonntagsblätter, but for economic and censorship issues it only went through three issues.

During the revolution he founded the democratic association Der deutsche Adler (The German Eagle), to which Simon Deutsch and other radical revolutionaries belonged. They supported a constitutional monarchy and used to meet in a pub that belonged to Sigmund's brother Leopold (Häusler 1982, p. 98). Engländer also penned articles for several revolutionary papers. In June 1848 he established the satirical journal Wiener Katzenmusik (Chariviari) that harbored anti-Habsburg sentiments and appeared several times per week with two double pages. ${ }^{57}$ From August onward, he additionally edited Die Reform: Politisch-soziales Tagblatt (The Reform: Social-Political Daily) that attracted radicals like Hermann Jellinek; the paper also marked Engländer's transition to social democracy and his advocacy for the rights of the Fourth Estate. Both papers were suppressed at the end of October 1848 and Engländer (like Deutsch) had to flee the city and the Habsburg Monarchy. However, Katzenmusik had established a kind of political satire that lived on in Vienna during the neo-absolutist and liberal eras (Häusler 1982, pp. 115-16). Engländer, on the other hand, shared the fate of repeated migrations with Deutsch and other radical revolutionaries. After a first stop in Leipzig he continued to Paris, where he conceptualized his socialist worldview (Engländer 1864), and finally settled in London in 1854. He obviously suffered from nostalgia and repeatedly considered returning to Vienna, but in the end remained in England. ${ }^{58}$

In conclusion, we might state that for all members of our reference group (including others that were associated with them), 1848 was a significant turning point in their lives. Before the revolution, their activities were hampered by millions of restrictions that left them discontented and disgruntled. First of all, the police surveillance and censorship laws of the Metternich system that impeded the growth and development of all intellectuals, impinged much harder upon Jews, whose legal situation was still more vulnerable. Especially in Vienna, where Jews had no legal right of residence, the difference was striking. After graduating from university, Jews could neither work in

53 On the prayer book cf. (Hecht 2011b, pp. 268-69).

54 On the printing house of Anton Schmid cf. (Hecht 2015a, pp. 44-47).

55 His first article was dedicated to art and entitled "David und Goliath: Als Vorwurf bildlicher Darstellung in den Gallerien Wiens." (Engländer 1843, pp. 1071-72)

56 Although it did not include Jewish topics, it was published by Schmid \& J.J. Busch, a printing house that was rather known for Jewish and Hebrew publications.

57 In August the paper changed its name to Wiener Charivari: Politisches Tagsblatt für Spott und Ernst mit Karrikaturen (Viennese Charivari: Political daily for mockery and solemnity, with caricatures).

58 Ddocumented, for example, in (Frankl 1910, p. 312). 
the academia nor in the civil service that provided ample job opportunities for their gentile peers. In the liberal (or 'free') professions, like journalism, on the other hand, they were fettered by the shackles of the authoritarian state and its censorship laws. In particular, the younger group members, i.e., the ones born in the 1820s, felt a strong urge to do away with a system that simultaneously thwarted their personal aspirations and inhibited political freedom. Like non-Jewish middle class intellectuals, they therefore joined the revolutionary ranks to fight for democratic representation and civil rights for all citizens of the Monarchy. While most of them were unwaveringly committed to German culture and German nationalism, all of them (with the exception of Engländer) aimed to implement the unification of the German nation under the leadership of the Habsburg Monarchy (Engländer's views on this question were ambivalent though, cf. (Häusler 1982, pp. 104-5).

However, the revolutionary drive was evidently linked to the age group under discussion. The Moravian born Wolfgang Wessely (1801-1870) (Kisch 1969) ${ }^{59}$, for instance, by and large shared the intellectual formation of some of our group members. He had studied law at Prague's Charles University in the 1820s; after graduating he worked as a private tutor for an affluent Jewish family in Vienna and upon his return to Prague was employed by the Jewish primary school in the city as a teacher of Jewish religion-hardly a satisfying career for an ambitious graduate from law school. Wessely resigned himself to this degradation and reaped the fruits of his loyalty after the revolution. Already, in 1849, he was appointed as a tutor at Prague's Law Faculty and in 1861 he became the first Jew to hold a full professorship in the Habsburg Monarchy. As expounded above, the younger generation of Moravian Jewish intellectuals (Engländer and Deutsch) were much less patient than Wessely; they counted among the most radical opponents of the Metternich regime. Moreover, they left the Habsburg Monarchy after the revolution for good, while the rest of the revolutionary refugees returned in the constitutional era at the latest. But even the most radical revolutionaries remained loyal to the Habsburg Monarchy in their way. When he was accused of spying for Prussia in France, the socialist Simon Deutsch even emphasized that an Austrian would never enter the paid services of Prussia (Miller 2010, pp. 387-88).

The remarkable loyalty and identification with the Habsburg Monarchy in the 1850s and the constitutional era (i.e., from 1867 onward) can be explained by the removal of legal discrimination combined with a high level of social integration. Some members of our sample were extremely successful in the political arena: Kompert was nominated councilor (Regierungsrat) in 1868, appointed as a regional supervisor of the educational system (Bezirksschulrat) in 1870 and elected to the City Council of Vienna in 1873; Kuranda was co-opted to the Imperial Assembly (Reichsrat) in 1861 and elected to the Viennese communal board in the constitutional era; in the latter forum also Neustadt received a seat. L.A. Frankl's brother Wilhelm was delegated to the Viennese communal board in 1861, whereas his brother David Bernhard was appointed to the equivalent position in Prague already in 1849 (Hecht 2016a, pp. 345-47). Although Jews succeeded only gradually to enter aspired positions in state administration and universities, they did not harbor hard feelings against the state, since they felt accepted by their non-Jewish peers and often even by nobility. Their Jewish, German, Habsburg and eventually also cosmopolitan identities seemed compatible and therefore unproblematic. Their fight for rights was neither particularistic (i.e., fight for Jewish emancipation alone) nor anti-Habsburg. Thanks to their education and intellectual sophistication they were confident that they belonged to the elite of the country. As opposed to the German Kaiserreich, where legal equality combined with social discrimination in the end led to disaster (Volkov 1990), social integration in the Habsburg Monarchy produced a self-assured segment of society that was positively inclined to contribute to the greater good. Hartmann's friend Alfred Meißner brilliantly summarized this feeling of belonging in the following words: 
Hartmann was a Jew, but to the best of my knowledge, he didn't suffer the pains that distress so many of today's Jews. He never experienced humiliations because of his descent. Then, in an era of humanism, [...] one chose to ignore the Jewishness of a Jew, and Judaism in general ((Meißner 1884) quoted according to (Steiger-Schumann 2015)).

Conflicts of Interest: The author declares no conflict of interest.

\section{References}

Amann, Paul. 1907. Leopold Komperts Literarische Anfänge. Prage: Carl Bellmann.

Archiv der Israelitischen Kultusgemeinde Wien. 1822. Geburtssmatriken. Vienna, Austria: Archiv der Israelitischen Kultusgemeinde Wien.

Archiv der Israelitischen Kultusgemeinde Wien. 1867. Trauungsmatriken Stadttempel. Vienna, Austria: Archiv der Israelitischen Kultusgemeinde Wien.

Archiv der Israelitischen Kultusgemeinde Wien. 1875. Sterbematriken, Adolf Neustadt. December 6, Vienna, Austria: Archiv der Israelitischen Kultusgemeinde Wien.

Bacher, Simon. 1881. Mizmor le-Kuranda: h.h. Gever Hakham be-oz Dibuvo, ha-Yoshev ba-Rishonah ben yo'etse ha-arets. Budapest: Mor Burian.

Beer, Peter. 1815. Die Macht der Religion. Ein Wort des Trostes, allen, denen der Krieg mittelbar oder unmittelbar, eine geliebte Person durch den Tod entrissen hat. Prague: F. J. Scholl.

Beer, Peter. 1839. Lebensgeschichte. Edited by Moritz Herrmann. Translated by L. H. Prague: Unknown publisher, p. 14.

Bourke, Eoin. 2001. Moritz Hartmann und Irland. In Bewegung im Reich der Immobilität: Revolutionen in der Habsburgermonarchie 1848-1849. Edited by Hubert Lengauer and Primus-Heinz Kucher. Vienna: Böhlau, pp. 427-41.

Central Archives for the History of the Jewish People. 1941. Tätigkeitsbericht über die auf dem Währinger Friedhof durchgeführten Exhumierungen ( $A / W$ 1515). Jerusalem, Israel: Central Archives for the History of the Jewish People.

Der österreichische Zuschauer: Zeitschrift für Kunst, Wissenschaft und geistiges Leben. 1850. Die Lumpaziokratie im Jahre 1848, oder: Was der Wolf den Gänsen predigt. Der österreichische Zuschauer: Zeitschrift für Kunst, Wissenschaft und geistiges Leben, June 29.

Deutsch, Simon, and Franz Gräffer. 1847. Jüdischer Plutarch. Sonntagsblätter, November 14.

Dollar, Stefanie. 1932. Die Sonntagsblätter von Ludwig August Frankl, 1842-1848. Unpublished Ph.D. thesis, University of Vienna, Vienna, Austria.

Donath, Oskar. 1912. Siegfried Kapper als Ghettodichter. Monatsschrift für Geschichte und Wissenschaft des Judentums 56: 513-45.

Donath, Oskar. 1934. Siegfried Kapper. In Jahrbuch der Gesellschaft für Geschichte der Juden in der ČSR 6. Prague: Taussig u. Taussig, pp. 323-442.

Doublier, Othmar. 1906. Kuranda, Ignaz. In Allgemeine Deutsche Biographie. 51 vols; Edited by the Historische Commission bei der Königl. Akademie der Wissenschaften. Leipzig: Duncker \& Humblot, pp. 445-50.

Duchkowitsch, Wolfgang. 2014. Medien: Aufklärung, Orientierung, Missbrauch vom 17. Jahrhundert bis zu Fernsehen und Video. Vienna and Berlin: Lit Verlag, p. 141.

Engländer, Hermann. 1824. Enkat Bene Temutha: Eine Sammlung Hochdeutscher Gebethe für Gebildete Israelitische Frauenzimmer. Prague: Scholl \& Landau.

Engländer, Sigmund. 1843. David und Goliath: Als Vorwurf bildlicher Darstellung in den Gallerien Wiens. Sonntagsblätter, November 5.

Engländer, Sigmund. 1864. Geschichte der französischen Arbeiter-Associationen. Hamburg: Hoffmann \& Campe.

Frankl, Ludwig August. 1828. Johann Pancyr (Böhmische Volkssage). Archiv für Geschichte, Statistik, Literatur und Kunst 19: 140-42.

Frankl, Ludwig August. 1836. Cristoforo Colombo: Romantisches Gedicht. Stuttgart: Brodhag'sche Buchhandlung, p. 7.

Frankl, Ludwig August. 1910. Erinnerungen. Edited by Stefan Hock. Prague: Calve'sche Universitätsbuchhandlung. 
Gasser, Wolfgang. 2010. Erlebte Revolution 1848/49: Das Jüdische Tagebuch des Journalisten Benjamin Kewall. Vienna and Munich: Böhlau and Oldenbourg Verlag, p. 76.

Gollance, Sonia. 2017. Harmonious Instability: (Mixed) Dancing and Partner Choice in German-Jewish and Yiddish Literature. Unpublished Ph.D. thesis, University of Pennsylvania, Philadelphia, PA, USA.

Hartmann, Moritz. 1843. Kindesweinen im Schlaf. Sonntagsblätter, November 26.

Häusler, Wolfgang. 1982. Sigmund Engländer-Kritiker des Vormärz, Satiriker der Wiener Revolution und Freund Friedrich Hebbels. In Juden im Vormärz und in der Revolution von 1848. Edited by Walter Grab and Julius Schoeps. Jahrbuch des Instituts für deutsche Geschichte der Universität Tel Aviv, Beiheft 5; Stuttgart: Burg-Verlag, pp. 83-137.

Hecht, Louise. 2004. Gib dem Knaben Unterricht nach seiner Weise (Spr. 22,6): Theorie und Praxis des modernen jüdischen Schulsystems in der Habsburger Monarchie. Jahrbuch der Österreichischen Gesellschaft zur Erforschung des 18. Jahrhunderts 18/19: 117-34.

Hecht, Louise. 2008. Ein Jüdischer Aufklärer in Böhmen: Der Pädagoge und Reformer Peter Beer (1758-1838). Köln: Böhlau, pp. 113-14.

Hecht, Louise. 2009. Kreative Geschichtsschreibung: Die Ramschak-Chronik und die Geschichte der Juden in Böhmen. In Zwischen Graetz und Dubnow: Jüdische Historiographie in Ostmitteleuropa im 19. und 20. Jahrhundert. Edited by François Guesnet. Leipzig: AVA-Akademische Verlagsanstalt, pp. 33-62.

Hecht, Louise. 2011a. Haskalah und jüdische Erziehung in den Ländern der Böhmischen Krone. Judaica Bohemiae XLVI Supplementum. Available online: https://www.academia.edu/5887483/Haskalah_und_j\% C3\%BCdische_Erziehung_in_den_L\%C3\%A4ndern_der_B\%C3\%B6hmischen_Krone (accessed on 13 June 2017).

Hecht, Louise. 2011b. The Haskalah in Bohemia and Moravia-A gendered perspective. In The Enlightenment in Bohemia: Religion, Morality and Multiculturalism. Edited by Ivo Cerman, Rita Krueger and Susan Reynolds. Oxford: Voltaire Foundation.

Hecht, Louise. 2014. Czech, German, Jewish, Cosmopolitan? The Writer Ludwig August Frankl. In A View from Elsewhere. Edited by Marcel Arbeit and Roman Trušník. Olomouc: Palacký University Olomouc, pp. 119-34.

Hecht, Louise. 2015a. Christian Printers as Agents of Jewish Modernization? Hebrew Printing Houses in Prague, Brno and Vienna, 1780-1850. Judaica Olomucensia 3: 30-52. Available online: http://www.jud.upol.cz/ fileadmin/jud/judaica/Judaica_Olomucensia_2015_1.pdf (accessed on 12 June 2017).

Hecht, Louise. 2015b. Toleranzpatente. In Enzyklopädie jüdischer Geschichte und Kultur. Edited by Dan Diner. Stuttgart: J. B. Metzler, vol. 6, pp. 137-41.

Hecht, Louise. 2016a. A Biographical Sketch. In Ludwig August Frankl. Vienna: Böhlau.

Hecht, Louise. 2016b. "Durch Wort und That": Motto und Credo. In Ludwig August Frankl. Edited by Louise Hecht. Vienna: Böhlau, pp. 291-321.

Hecht, Louise. 2016c. Ludwig August Frankl (1810-1894): Eine Jüdische Biographie Zwischen Okzident und Orient. Edited by Louise Hecht. Vienna: Böhlau.

Hecht, Dieter J. 2016d. Self-Assertion in the Public Sphere: The Jewish Press on the Eve of Legal Emancipation. Religions 7: 109. Available online: http:/ /www.mdpi.com/2077-1444/7/8/109 (accessed 22 December 2016).

Hecht, Louise. n.d. Normalschulen. The YIVO-Encyclopedia of Jews in Eastern Europe. Available online: http:/ / www.yivoencyclopedia.org/article.aspx/Normalschulen (accessed on 29 May 2017).

Hess, Jonathan M. 2010. Middlebrow Literature and the Making of German-Jewish Identity. Stanford: Stanford University Press, chp. 2; pp. 72-110.

Heuer, Renate. 1992-2013. Lexikon deutsch-jüdischer Autoren. Edited by Renate Heuer. 21 vols; Berlin: de Gruyter. Hock, Stefan. 1906. Leopold Komperts sämtliche Werke in zehn Bänden. Edited by Stefan Hock. Lepzig: Max Hesses Verlag, vol. 1, pp. v-lviii.

Kaplan, Marion A. 1991. The Making of the Jewish Middle Class: Women, Family, and Identity in Imperial Germany. New York and Oxford: Oxford University Press.

Kapper, Siegfried. 1844. Slavische Melodien. Leipzig: Eichhorn.

Kapper, Siegfried. 1846. České listy. Prague: Calve.

Kestenberg-Gladstein, Ruth. 1969. Neuere Geschichte der Juden in den Böhmischen Ländern. Tübingen: Mohr Siebeck, pp. 1-3, 34-40.

Kestenberg-Gladstein, Ruth. 2002. Heraus aus der 'Gasse': Böhmens Juden im 19. Jahrhundert. Münster: Lit Verlag, pp. 74-88. 
Kieval, Hillel. 1987. Caution's Progress: The Modernization of Jewish Life in Prague, 1780-1830. In Toward Modernity: The European Jewish Model. Edited by Jacob Katz. New Brunswick: Transaction Books, pp. 71-105. Kieval, Hillel. 2000. Languages of Community: The Jewish Experience in the Czech Lands. Berkeley: University of California Press, p. 66.

Kisch, Guido. 1969. Die Prager Universität und die Juden, 1348-1848. Amsterdam: B.R. Grüne, First published 1935. Kompert, Leopold. 1842. Preßburg und der Königshügel. Reisebild. Sonntagsblätter, June 10.

Kompert, Leopold. 1845. Aus dem Norden Ungarn's. Sonntagsblätter, December 14.

Kompert, Leopold. 1846a. Der Schnorrer. Aus dem böhmisch-jüdischen Leben. Sonntagsblätter, February 1.

Kompert, Leopold. 1846b. Aus dem Ghetto. 1. Das Verbrennen des Gesäuerten. Sonntagsblätter, May 31.

Kompert, Leopold. 1848a. Aus dem Ghetto: Geschichten. Leipzig: Fr. Grunow.

Kompert, Leopold. 1848b. Nicht sterben können. Eine Legende aus dem Ghetto. Sonntagsblätter, January 2.

Krafft, Albrecht, and Simon Deutsch. 1847. Sonntagsblätter, January 31.

Krejčí, Jan. 1911. Příspěvek k poznání básnické činnosti Siegfrieda Kappera. Prague: Česká akademie věd a umění. Landau, Yehezkel. 1966. Derushei ha-Tselah. Jerusalem: Be-Feirush uva-Remez.

Laß, Hans. 1963. Moritz Hartmann: Entwicklungsstufen des Lebens und Gestaltwandel des Werkes. Ph.D. thesis, University of Hamburg, Hamburg, Germany.

Macura, Vladimír. 1998. Problems and Paradoxes of the National Revival. In Bohemia in History. Edited by Mikuláš Teich. Cambridge: Cambridge University Press, pp. 182-97.

Meißner, Alfred. 1884. Geschichte Meines Lebens. Vienna: Karl Prochaska, p. 56.

Mendes-Flohr, Paul, and Jehuda Reinharz. 1995. A partial English translation appeared. In The Jew in the Modern World. Oxford: Oxford University Press, pp. 70-74.

Miller, Michael L. 2010. From Liberal Nationalism to Cosmopolitan Patriotism: Simon Deutsch and 1848s in Exile. European Review of History, March 17.

Morgenpost. 1877. Noitzen. Morgenpost, January 18.

Neue Freie Presse. 1867. Hof-und Personalnachrichten. Neue Freie Presse, September 11.

Neue Freie Presse. 1877a. Abendblatt: Begräbnis von Simon Deutsch. Neue Freie Presse, May 19.

Neue Freie Presse. 1877b. Obituary for Simon Deutsch. Neue Freie Presse, March 31.

Neues Fremdenblatt. 1863. Neues Fremdenblatt, June 1.

Neustadt, Adolf. 1869. Biographisches Lexikon des Kaiserthums Oesterreich. Edited by Constantin Wurzbach. Vienna: Hof-und Staatsdruckerei, vol. 20, pp. 299-305.

Neustadt, Adolf. 1875. Sterbematriken. Archiv der Israelitischen Kultusgemeinde Wien, December 6.

Niedhammer, Martina. 2013. Nur eine "Geld-Emancipation"? Loyalitäten und Lebenswelten des Prager jüdischen Großbürgertums 1800-1867. Göttingen: Vandenhoeck \& Ruprecht, pp. 91-92.

Pazi, Margarita. 1973. Moritz Hartmann, der Reimchronist des Frankfurter Parlaments. Jahrbuch des Instituts für Deutsche Geschichte der Universität Tel Aviv 2: 239-66.

Pazi, Margarita. 1976. Die Juden in der ersten deutschen Nationalversammlung, 1848/49. Jahrbuch des Instituts für Deutsche Geschichte der Universität Tel Aviv 5: 176-209.

Petrbok, Václav. 2016. Ludwig August Frankl als tschechischer Dichter. In Ludwig August Frankl. Edited by Louise Hecht. Vienna: Böhlau, pp. 89-120.

Pribram, Alfred Francis. 1918. Handwriting from 13 May 1781. In Urkunden und Akten zur Geschichte der Juden in Wien. Erste Abteilung, Allgemeiner Teil, 1526-1847 (1849). Vienna and Leipzig: Wilhelm Braumüller, pp. 440-42.

Riff, Michael A. 1983. Jüdische Schriftsteller und das Dilemma der Assimilation im Böhmischen Vormärz. In Juden im Vormärz und in der Revolution von 1848. Edited by Walter Grab and Julius H. Schoeps. Jahrbuch des Instituts für deutsche Geschichte der Universität Tel Aviv, Beiheft 5; Stuttgart: Burg Verlag, pp. 58-82.

Sadowsi, Dirk. 2010. Haskala und Lebenswelt. Herz Homberg und die Jüdischen Deutschen Schulen in Galizien 1782-1806. Göttingen: Vandenhoeck \& Ruprecht, pp. 374-92.

Saperstein, Marc. 1989. Jewish Preaching 1200-1800: An Anthology. New Haven: Yale University Press, pp. $361-73$. Schumacher, Andreas. 1844. Theater. Sonntagsblätter, November 24.

Seidlitz, Julius. 1837. [= Isaac Jeitteles]. In Die Poesie und die Poeten in Oestereich im Jahre 1836. Grimma: J. M. Gebhardt. 
Silber, Michael K. 2004. From Tolerated Aliens to Citizen Solders: Jewish Military Service in the Era of Joseph II. In Constructing Nationalities in East Central Europe. Edited by Pieter M. Judson and Marsha L. Rozenblit. New York: Berghahn, pp. 19-36.

Silber, Michael K. n.d.a. Adolf Neustadt. The YIVO-Encyclopedia of Jews in Eastern Europe. Available online: http://www.yivoencyclopedia.org/article.aspx/Neustadt_Adolf (accessed on 29 May 2017).

Silber, Michael K. n.d.b. Josephinian Reforms. The YIVO-Encyclopedia of Jews in Eastern Europe. Available online: http://www.yivoencyclopedia.org/article.aspx/Josephinian_Reforms (accessed on 29 May 2017).

Sonntagsblätter. 1845. Sonntagsblätter, March 30.

Sonntagsblätter. 1848. Sonntagsblätter, March 19.

Steiger-Schumann, Ingrid. 2015. Jüdisch-Christliche Liebesbeziehungen im Werk Leopold Komperts. Berlin: Walter de Gruyter, p. 82.

Steines, Patricia. 1993. Hunderttausend Steine: Grabstellen großer Österreicher jüdischer Konfession auf dem Wiener Zentralfriedhof. Vienna: Falter Verlag, p. 307.

Szanto, Simon. 1881. Dr. Ignaz Kuranda. Die Neuzeit, April 29.

Volkov, Shulamit. 1990. Jüdisches Leben und Antisemitismus im 19. und 20. Jahrhundert. München: C. H. Beck Verlag, pp. 126-29, 144-45.

Wandruszka, Adam. 1980. Großdeutsche und kleindeutsche Ideologie 1840-1871. In Deutschland und Österreich: Ein bilaterales Geschichtsbuch. Edited by Robert Kann and Friedrich Prinz. Vienna: Jugend \& Volk, pp. 110-42. Weisel, Naphtali Herz. 1781/1782. Divrey Shalom ve-Emet. Berlin: Unknown publisher.

Wessely, Hartwig. 1782. Worte der Wahrheit und des Friedens an die gesammte jüdische Nation, vorzüglich an diejenigen, so unter dem Schutze des glorreichen und großmächtigen Kaisers Joseph II. wohnen. Vienna: J. F. Edler von Schönfeld.

Wiener Zeitung. 1832. Wiener Zeitung, February 23.

Wistrich, Robert S. 1990. The Jews of Vienna in the Age of Franz Joseph. Oxford: Oxford University Press, pp. 140-42. Wittner, Otto. 1903. Moritz Hartmanns Jugend. Vienna: Verlag des Verfassers, pp. 9-11.

Wittner, Otto. 1906. Moritz Hartmanns Leben und Werke: Ein Beitrag zur politischen und literarischen Geschichte Deutschlands im 19. Jahrhundert. In Moritz Hartmann. Gesammelte Werke. Prague: J. G. Calvesche Hof-und Universitätsbuchhandlung, vol. 1, p. 14.

Wittner, Otto. 1911. Briefe aus dem Vormärz: Eine Sammlung aus dem Nachlaß Moritz Hartmanns. Edited and prefaced by Otto Wittner; Prague: Calvesche Hof-und Universitätsbuchhandlung, p. viii.

Wolf, Gerson. 1861. Vom Ersten Zum Zweiten Tempel.Geschichte der Israelitischen Kultusgemeinde in Wien (1820-1860). Vienna: Wilhelm Braumüller, pp. 1-8.

Wolkan, Rudolf. 1921. Briefe von Moritz Hartmann. Vienna: Nikola Verlag. 